\title{
Influence of Smoking Methods and Refrigeration Storage on Physiochemical Quality Parameters of Catfish (Clarias Gariepinus) Fillets
}

\author{
Adel A El-Lahamy ${ }^{1 *}$, Khalil I Khalil ${ }^{2}$, Shaban A El-Sherif ${ }^{1}$ and Awad A Mahmud ${ }^{2}$ \\ ${ }^{1}$ Fish Processing Technology Laboratory, National Institute of Oceanography and Fisheries, Egypt \\ ${ }^{2}$ Food Science and Technology Department, Fayoum University, Egypt
}

Submission: August 03, 2018; Published: January 16, 2019

Corresponding author: Adel A El-Lahamy, Fish Processing Technology Laboratory, National Institute of Oceanography and Fisheries, Egypt

\begin{abstract}
The current study was carried out to investigate the effect of smoking methods (Hot\&cold) and refrigeration storage for 40days on physiochemical quality parameters of Catfish (Clarias gariepinus) fillets. Chemical quality analysis of Catfish fillets indicated that TVB-N and TBA significantly $(\mathrm{P}<0.05)$ increased in the smoked Catfish samples in comparison with fresh unsmoked fish while pH value of smoked fillets slightly decreased. At the end of 40 days storage, TVB-N values of hot and cold smoked samples were determined by $30.17 \pm 0.479$ and $32.2 \pm 0.173$ $\mathrm{mg} / 100 \mathrm{~g}$, respectively while TBA values of hot and cold smoked fillets increased up to $2.41 \pm 0.173$ and $2.26 \pm 0.115 \mathrm{mg}$ malonaldhyde/ $\mathrm{kg}$, respectively. The $\mathrm{pH}$ values slightly increased up to $6.22 \pm 0.034$ and 6.440 .046 for hot and cold smoked samples, respectively at the end of 40 days of refrigeration storage.
\end{abstract}

Keywords: Catfish; TVB-N; TBA; Smoking methods; Refrigeration storage

Abbreviations: TVB-N: Total Volatile Basic Nitrogen; TBA: Thiobarbituric Acids; NIOF: National Institute of Oceanography and Fisheries

\section{Introduction}

Fish and fishery products have long been recognized as healthy foods with excellent nutritional value, providing highquality protein, minerals, vitamins, essential fatty acids and trace elements. Fish is widely consumed in many parts of the world by humans due to its high content of good protein that characterizes by an excellent amino acid composition and easily digestibility [1]. Smoking is a traditional preservation technology that combines the effect of salting, deposition of smoke components and drying. It produces the characteristic taste and color that is much appreciated by consumers. Smoke contains many different components, such as aldehydes, ketones, alcohols, acids, hydrocarbons, esters, phenols, ethers, etc. [2]. The drying effect during smoking, along with the antioxidant and antimicrobial effects of the smoke, allow smoked products to have extended shelf-life [3]. Smoking has become a mean of offering diversified, high value-added products as an additional marketing option for certain fish species where fresh consumption becomes limited [4].

Total volatile basic nitrogen (TVB-N) is one of the most important criteria in the quality evaluation of fish products. Thiobarbituric acids (TBA) represent the degree of rancidity in the fresh and processed fish products and usually determined as the concentration of malonaldhyed in the products. Several studies were carried out to follow up quality changes in smokes fish products during storage Abd El- Mageed [5], Kolsarici and Ozkaya [6], Yanar [7], Bilgin et al. [8], Daramola et al. [9], Koral et al. [10], Abo-Taleb et al. [11] and Frank et al. [12]. Huss [13] reported that the acceptable limit of total volatile basic nitrogen (TVB-N) value in fresh fish flesh was $35 \mathrm{mg} / 100 \mathrm{~g}$.Similarly, Connell [14] observed that the acceptable levels of total volatile basic nitrogen (TVB-N) value in raw fish were ranged from 35 to $40 \mathrm{mg} / 100 \mathrm{~g}$. Shen [15] suggested the standards of TVB-N values for freshness of fish as follows; fresh fish: $<15 \mathrm{mg} / 100 \mathrm{~g}$, sub fresh: $15-25 \mathrm{mg} / 100 \mathrm{~g}$ and deteriorated fish $<25 \mathrm{mg} / 100 \mathrm{~g}$. While, Lopez Caballero et al. [16] found that the acceptable levels of total volatile basic nitrogen (TVB-N) value of fresh fish ranged from 25 to $30 \mathrm{mg} / 100 \mathrm{~g}$. The TBA value should be less than 3.0 $\mathrm{mg}$ malonaldhyde/kg in the perfect quality material and not be more than $5.0 \mathrm{mg}$ malonaldhyde / $\mathrm{kg}$ in good quality material and consumption limits were from 7.0 to $8.0 \mathrm{mg}$ malonaldhyde/kg [17]. $\mathrm{pH}$ value has been used for the evaluation of fish freshness and as an index of the quality of fish products [18]. In general, $\mathrm{pH}$ value of living fish is in the range of 6.3 to $7.0[19,20]$. 


\section{Materials and Methods}

\section{Materials}

\section{Fish sample}

I. Catfish (Clarias gariepinus): Fresh Catfish (Clarias gariepinus) samples were obtained from Wadi EI-Rayan Lake, Fayoum Governorate, Egypt, during August 2015. Averages of weight and length ranged between $1.8-2.3 \mathrm{~kg}$ and $56-60 \mathrm{~cm}$, respectively. The fish samples were transported in ice-box to the laboratory of Fish Processing Technology, Shakshouk Station for Fish Research, National Institute of Oceanography and Fisheries (NIOF), Fayoum Governorate, Egypt. Fish samples were beheaded, gutted and washed gently with tap water then skinned and filleted manually. The edible part (fillets) of Catfish was about $48 \%$.

\section{Processing methods}

Smoking methods: Smoked Catfish fillets were produced by following the traditional methods of cold and hot smoking using smoking oven at Shakshouk Fish Research Station (NIOF). The conditions of smoking are described in Table 1 as reported by Abd El-Mageed [5] (Table 1).

Table 1: Conditions of smoking

\begin{tabular}{|c|c|c|}
\hline Smoking Parameters & Cold Smoking & Hot Smoking \\
\hline Brining (\%Nacl) & $10 \%$ & $10 \%$ \\
\hline Brining Period (h) & 1 & 1 \\
\hline Air Drying Period (h) & 3 & 3 \\
\hline Temperature ( ${ }^{\mathbf{C}} \mathbf{)}$ & $30-40$ & $50-90$ \\
\hline Smoking Period (h) & $11-12$ & $5-6$ \\
\hline The Source of Fuel & sawdust & sawdust \\
\hline
\end{tabular}

\section{Physiochemical quality parameters}

Total volatile basic- nitrogen (TVB-N): Total volatile basic-nitrogen was determined by macro-distillation method as described by Pearson [21] and the results obtained were expressed as mg TVB-N/100g fresh sample.

Thiobarbituric acid (TBA): Malonaldehyde content was calorimetrically determined as described by Pearson [21] and the results were expressed as mg malonaldhye/kg of sample. Table 2: Physicochemical quality characteristics of fresh and smoked
pH: The $\mathrm{pH}$ value was measured according to A.O.A.C. [22] as the follows: $10 \mathrm{~g}$ of the minced sample were homogenized with $100 \mathrm{ml}$ of distilled water and the mixture was filtered by using filter paper. The $\mathrm{pH}$ value of the filtrate was measured using $\mathrm{pH}$ meter with combined electrode.

\section{Effect of smoking methods on Catfish fillets}

Physiochemical Quality Parameters: The effect of smoking methods on the physicochemical quality parameters was studied. Total volatile basic nitrogen (TVB-N), Thiobarbituric acid (TBA) as well as $\mathrm{pH}$ of Catfish smoked by hot and cold smoking methods was determined and the results obtained are shown in Table 2.

Total Volatile Basic Nitrogen (TVB-N): The results showed that TVB-N significantly $(\mathrm{P}<0.05)$ increased in the smoked Catfish samples in comparison with fresh unsmoked fish. It was found that TVB-N values in hot and cold smoked samples were $17.80 \pm 0.173$ and $18.95 \pm 0.202 \mathrm{mg} / 100 \mathrm{~g}$, respectively. Similar results reported by Yanar [7] and Koral et al. [10]. Increasing TVB-N after smoking process most likely caused by an autolytic process which produces volatile amine compounds. The higher value of TVB-N in cold smoked fillets might be attributed to the action of protein hydrolysis caused by enzymes during the longer time and lower temperature used in cold smoking [5] (Table 2).

Thiobarbaturic acid (TBA): During smoking process, Catfish fillets were exposed to heating and atmospheric oxygen. These factors can accelerate the oxidation of fish lipids, resulting in the increase of TBA. As shown in Table 2, TBA values for raw Catfish fillets significantly $(\mathrm{P}<0.05)$ increased from $0.23 \pm 0.017$ to $0.44 \pm 0.023$ and $0.29 \pm 0.011 \mathrm{mg}$ malonaldehyde/ $\mathrm{kg}$ in hot and cold smoked samples, respectively. However, the thiobarbituric acid values in the smoked samples were less than the levels reported for the rejected samples and were still acceptable. This observation is in agreement with the results reported by El-Akeel [23], Yanar [7] and Goulas and Kontominos [24]. The higher TBA value observed in hot smoked sample may be attributed to partial dehydration of fish and more oxidation of the unsaturated fatty acids as a result of smoking at relatively high temperatures (up to $70^{\circ} \mathrm{C}$ ). This observation is in agreement with the results reported by Goktepe and Moody [25] who observed a two-fold increase in TBA value of raw Catfish after hot smoking at temperature of $82^{\circ} \mathrm{C}$.

\begin{tabular}{|c|c|c|c|c|c|}
\hline \multirow{2}{*}{ Parameters } & \multicolumn{3}{|c|}{ Catfish Fillets } & \multirow{2}{*}{ Sig. } & \multirow{2}{*}{ LSD } \\
\hline & Fresh & Hot Smoked & Cold Smoked & & \\
\hline TVB-N (mg/100g) & $13.7 \pm 0.09$ & $17.80 \pm 0.17$ & $18.95 \pm 0.20$ & 0 & 0.23 \\
\hline TBA (mg malonaldhyde/ kg) & $0.23 \pm 0.01$ & $0.44 \pm 0.02$ & $0.29 \pm 0.01$ & 0 & 0.048 \\
\hline pH & $6.4 \pm 0.08$ & $6.10 \pm 0.04$ & $6.20 \pm 0.01$ & 0.026 & 0.154 \\
\hline
\end{tabular}

pH: As shown in Table 2, pH value of raw Catfish fillets was $6.4 \pm 0.086$ while hot and cold Catfish fillets showed $\mathrm{pH}$ values of $6.10 \pm 0.046$ and $6.20 \pm 0.011$, respectively. The lower $\mathrm{pH}$ values of smoked samples might be attributed to the absorption of some organic acids from the smoke by the flesh during smoking processing. Similar results were reported by Yanar [7].
Physiochemical Quality Parameters: The chemical quality attributes commonly used to determine the quality as well as the shelf life of fish and fish products are total volatile basic nitrogen (TVB-N), thiobarbituric acid (TBA) and $\mathrm{pH}$ value. These quality attributes of smoked fish fillets are the major factors which affect the overall acceptability of these products for human 
consumption. The influence of storage conditions on these parameters of hot and cold smoked Catfish fillets was studied during refrigeration storage at $4 \pm 1^{\circ} \mathrm{C}$.

Total Volatile Basic Nitrogen (TVB-N): Total volatile basic nitrogen of fish and fish products is an index to the degree of putrefaction, decomposition and degree of the breakdown of proteinases constituents. TVB-N contents of hot and cold smoked Catfish fillets were determined periodically at intervals of 5 days during refrigeration storage for 40 days. The results obtained are shown in Table 3. The initial values of TVB-N contents of hot and cold smoked Catfish fillets were determined by $16.8 \pm 0.173$ and $18.95 \pm 0.202 \mathrm{mg} / 100 \mathrm{~g}$ (on wet weight basis), respectively. During storage, it was observed that TVB-N values of the samples gradually increased as the storage periods extended. At the end of 40 days storage, TVB- $\mathrm{N}$ values of hot and cold smoked samples

Table 3: Changes in TVB-N content $(\mathrm{mg} / 100 \mathrm{~g})$ of smoked Catfish fillets during refrigeration storage at $4.0 \pm 1{ }^{\circ} \mathrm{C}$.

\begin{tabular}{|c|c|c|c|c|}
\hline \multirow{2}{*}{ Storage Time (Days) } & \multicolumn{2}{|c|}{ TVB-N Content (mg/100g) } & \multirow{2}{*}{ Sig. } \\
\cline { 2 - 5 } & Hot smoked fillets & Cold smoked fillets & \multirow{2}{*}{ L.S.D } \\
\hline 0 & $16.8 \pm 0.173$ & $18.95 \pm 0.202$ & 0.001 & 0.531 \\
\hline 5 & $17.36 \pm 0.173$ & $19.76 \pm 0.288$ & 0.002 & 0.673 \\
\hline 10 & $21.28 \pm 0.161$ & $22.58 \pm 0.420$ & 0.02 & 0.901 \\
\hline 15 & $22.54 \pm 0.138$ & $23.98 \pm 0.277$ & 0.01 & 0.619 \\
\hline 20 & $22.55 \pm 0.317$ & $23.42 \pm 0.115$ & 0.062 & 0.675 \\
\hline 25 & $24.82 \pm 0.577$ & $26.77 \pm 0.444$ & 0.055 & 0.739 \\
\hline 30 & $25 \pm 0.288$ & $26.98 \pm 0.230$ & 0.006 & 0.526 \\
\hline 35 & $27.44 \pm 0.230$ & $29.22 \pm 0.127$ & 0.003 & 1.01 \\
\hline 40 & $30.17 \pm 0.479$ & $32.2 \pm 0.173$ & 0.016 & - \\
\hline Sig. & 0 & 0 & - & - \\
\hline
\end{tabular}

-Data are presented as mean \pm SE of 3 replicates. $-S E$ : standard error. -Significant difference at $P<0.05$.

Thiobarbituric (TBA): Thiobarbituric (TBA) is widely used as an indicator for the degree of lipid oxidation and the presence of TBA reactive substances is due to the second stage of autoxidation. TBA values for hot and cold smoked Catfish fillets during refrigeration storage were determined as malonaldhyde (mg/kg) and data obtained are presented in Table 4. Initially, TBA values of hot and cold smoked Catfish fillets samples were $0.44 \pm 0.023$ and $0.29 \pm 0.011 \mathrm{mg}$ malonaldhyde $/ \mathrm{kg}$, respectively. was determined by $30.17 \pm 0.479$ and $32.2 \pm 0.173 \mathrm{mg} / 100 \mathrm{~g}$ (wet weight basis), respectively.

Increasing TVB-N values during storage was attributed to the activity of endogenous and microbial protolytic enzymes which results in breakdown of proteins to volatile nitrogenous compounds [26,27] correlated between the quality of fish products and limits of TVBN as very good up to $25 \mathrm{mg} / 100 \mathrm{~g}$, good up to $30 \mathrm{mg} / 100 \mathrm{~g}$, marketable up to $35 \mathrm{mg} / 100 \mathrm{mg}$ and spoilt more than $35 \mathrm{mg} / 100 \mathrm{~g}$. Accordingly, it could be concluded the good quality of the smoked catfish fillets products even after 35 days of refrigeration storage. These results are in agreement with those reported by Abd El-Mageed [5] on smoked Silver Carp fillets and El-Akeel [23] on Catfish Yanar [7] on Catfish and Koral et al. [10] on Garfish (Table 3).
During refrigeration storage of the smoked samples, TBA values showed a gradual increase as the storage time prolonged. At the end of storage period (40 days), TBA values of hot and cold smoked fillets increased up to $2.41 \pm 0.173$ and $2.26 \pm 0.115$ $\mathrm{mg}$ malonaldhyde/kg, respectively. It is clearly observed that storage time had the pronounced effect on the production and concentration of the lipid oxidation products that were determined as malonaldhyde.

Table 4: Changes in TBA content (mg malonaldhyde/kg) of smoked Catfish fillets during refrigeration storage at $4.0 \pm 1{ }^{\circ} \mathrm{C}$.

\begin{tabular}{|c|c|c|c|c|}
\hline \multirow{2}{*}{ Storage Time (Days) } & \multicolumn{2}{|c|}{ TBA Value (mg/malonalhyade/kg) } & \multirow{2}{*}{ Sig. } & \multirow{2}{*}{ L.S.D } \\
\cline { 2 - 5 } & Hot Smoked Fillets & Cold Smoked Fillets & 0.004 & 0.051 \\
\hline 0 & $0.44 \pm 0.023$ & $0.29 \pm 0.011$ & 0.002 & 0.073 \\
\hline 5 & $0.60 \pm 0.028$ & $0.63 \pm 0.404$ & 0.088 & 0.225 \\
\hline 10 & $0.88 \pm 0.103$ & $1.04 \pm 0.080$ & 0.013 & 0.35 \\
\hline 15 & $1.06 \pm 0.173$ & $1.80 \pm 0.029$ & 0.012 & 0.23 \\
\hline 20 & $1.54 \pm 0.080$ & $1.89 \pm 0.115$ & 0.347 & 0.282 \\
\hline 25 & $2.04 \pm 0.080$ & $1.93 \pm 0.144$ & 0.212 & 0.375 \\
\hline 35 & $2.21 \pm 0.121$ & $2.02 \pm 0.196$ & 0.259 & 0.563 \\
\hline 40 & $2.39 \pm 0.202$ & $2.26 \pm 0.115$ & 0.511 & 0.416 \\
\hline
\end{tabular}




\section{Oceanography \& Fisheries Open access Journal}

\begin{tabular}{|c|c|c|c|c|}
\hline Sig. & 0 & 0 & - & - \\
\hline L.S.D & 0.354 & 0.292 & - & - \\
\hline
\end{tabular}

-Data are presented as mean \pm SE of 3 replicates. $-S E$ : standard error. -Significant difference at $P<0.05$.

The observed increase in TBA values for hot and cold smoked Catfish fillets were mainly because of both the autoxidation of fish fat and the formation of some TBA-reaction substances during storage [23]. The TBA value should be less than $3.0 \mathrm{mg}$ malonaldhyde $/ \mathrm{kg}$ in the perfect quality material and not be more than $5.0 \mathrm{mg}$ malonaldhyde / $\mathrm{kg}$ in good quality material and consumption limits were from 7.0 to $8.0 \mathrm{mg}$ malonaldhyde/kg [17]. In the present study, the highest value of TBA was determined by $2.41 \pm 0.173 \mathrm{mg}$ malonaldhyde/ $\mathrm{kg}$ for hot smoked Catfish fillets sample indicating the good quality of the different samples of smoked Catfish fillets even after 40 days of refrigeration storage. It was observed that TBA values for cold smoked Catfish samples were lower than those determined in the hot smoked samples and after 40 days storage the maximum value determined was $2.26 \mathrm{mg}$ malonaldhyde / $\mathrm{kg}$. This observation could be attributed to the effectiveness of the smoke antioxidants which may be more concentrated in cold smoking than in hot smoking. Similar results were reported with hot and cold smoked Silver Carp fillets, smoked Catfish and smoked Garfish $[5,7,10]$ (Table 4).

pH: The $\mathrm{pH}$ is among the most critical factors affecting microbial growth and spoilage of foods. $\mathrm{pH}$ value was measured in smoked Catfish fillets during refrigeration storage and the results obtained are illustrated in Table 5. As shown in Table 5 , the initial $\mathrm{pH}$ values for hot and cold smoked samples were almost the same $(6.1 \pm 0.046$ and $6.2 \pm 0.011)$. These initial values slightly increased up to $6.22 \pm 0.034$ and $6.44 \pm 0.046$ for hot and cold smoked samples, respectively at the end of 40 days of refrigeration storage. which could be due to the enzymatic degradation of fish muscle components [28]. Rising $\mathrm{pH}$ during storage also may be due to formation of dimethyl amine from trimethylamine oxide [29]. $\mathrm{pH}$ values between $6.8-7.0$ were proposed as acceptance limit of fish, while values above 7.0 indicate the spoilage $[30,31]$. These results are coincided with those obtained by [5,7] Daramola et al. [9] and Frank et al, [12] who reported that the $\mathrm{pH}$ value of smoked fish was slightly elevated during storage [32] (Table 5).

Table 5: Changes in $\mathrm{pH}$ value of smoked Catfish fillets during refrigeration storage at $4.0 \pm 1^{\circ} \mathrm{C}$.

\begin{tabular}{|c|c|c|c|c|}
\hline \multirow{2}{*}{ Storage Time (Days) } & \multicolumn{2}{|c|}{ pH Value } & \multirow{2}{*}{ Sig. } & \multirow{2}{*}{ L.S.D } \\
\cline { 2 - 5 } & Hot Smoked Fillets & Cold Smoked Fillets & 0.104 & 0.089 \\
\hline 0 & $6.10 \pm 0.046$ & $6.20 \pm 0.011$ & 0.062 & 0.073 \\
\hline 5 & $6.11 \pm 0.034$ & $6.20 \pm 0.005$ & 0.11 & 0.089 \\
\hline 10 & $6.13 \pm 0.040$ & $6.22 \pm 0.017$ & 0.127 & 0.163 \\
\hline 15 & $6.14 \pm 0.028$ & $6.24 \pm 0.074$ & 0.032 & 0.051 \\
\hline 20 & $6.16 \pm 0.011$ & $6.26 \pm 0.028$ & 0.022 & 0.073 \\
\hline 25 & $6.17 \pm 0.017$ & $6.31 \pm 0.034$ & 0.048 & 0.115 \\
\hline 30 & $6.19 \pm 0.051$ & $6.35 \pm 0.023$ & 0.005 & 0.073 \\
\hline 35 & $6.19 \pm 0.040$ & $6.42 \pm 0.005$ & 0.019 & 0.115 \\
\hline 40 & $6.22 \pm 0.034$ & $6.44 \pm 0.046$ & - & - \\
\hline Sig. & 0.34 & 0 & - & - \\
\hline
\end{tabular}

-Data are presented as mean \pm SE of 3 replicates. $-S E$ : standard error. -Significant difference at $P<0.05$.

\section{References}

1. Venugopal V, Chawla SP, Nair PMJ (1996) Spray dried protein powder from threadfin bream: Preparation, properties and comparison with fpc type-b. Journal of Muscle Foods banner 7(1): 55-77.

2. Doe PE (1998) Fish Drying and Smoking, Production and Quality. In: CRC Press, Technomic Publishing Co, US, 89-115.

3. Eyo AA (2001) Fish Processing Technology in the Tropics. In: Published by National Institute for Freshwater Fisheries Research, University of Ilorin Press, Nigeria, PP. 403

4. Gómez-Guillén MC, Gómez-Estaca J, Giménez B, Montero P (2009) Alternative fish species for cold-smoking process. Int J Food Sci Technol 44: 1525-1535.

5. Abd El- Mageed SA (1994) Chemical and technological studies on fish smoking. Thesis, Faculty of agriculture, Al-Azhar University.
6. Kolsarici N, Ozkaya O (1998) Effect of smoking methods on shelf-life of Rainbow trout (Salmo gairdneri) Turk. J Vet Anim Sci 22(3): 273-284.

7. Yanar Y (2007) Quality changes of hot smoked Catfish (Clarias gariepinus) during refrigerated storage. Journal of Muscle Foods 18(4): 391-400.

8. Bilgin S, Ulusayin M, Izci L, Gunlu A (2008) The Determination of the Shelf Life and Some Nutritional Components of Gilthead Seabream (Sparus aurata L, 1758) after Cold and Hot Smoking. Turkish Journal of Veterinary and Animal Sciences 32(1): 49-56.

9. Daramola JA, Kester CT, Allo OO (2013) Biochemical Evaluation of HotSmoked African Catfish (Clarias gariepinus) Sampled from Sango and Ota Markets in Ogun State. Pacific Journal of Science and Technology 14: 380-386.

10. Koral S, Köse S, Tufan B (2009) Investigating the Quality Changes of Raw and Hot Smoked Garfish (Belone belone euxini, Günther, 1866) at 
Ambient and Refrigerated Temperatures. Turkish Journal of Fisheries and Aquatic Sciences 9(1): 53-58.

11. Abo-Taleb M, El-Sherif SA, Ibrahim SM (2011) Influence of smoking methods and cold storage on quality of Silver carp (Hypophthalmichthys molitrix) fillets. Fayoum J Agric Res \& Dev

12. Frank F, Xu Y, jiang Q, Xia W (2014) Protective effects of garlic (Alliumsativum and ginger Zingiber officinale) on physicochemical and microbial attributes of liquid smoked Silver carp (Hypophthalmichthys molitrix) wrapped in aluminium foil during chilled storage. African Food Sci 8(1): 1-8.

13. Huss HH (1998) Fresh fish-quality and quality changes: A training manual prepared for the FAO/DANIDA training programme on fish technology and quality control. In: FAO, Italy.

14. Connell JJ (1990) Control of Fish Quality. In: Fishing News Book a Division of Black well Scientific Publication, UK.

15. Shen L (1996) Amperometric determination of freshness by hypoxanthine biosensor. Journal of the Science of Food Agriculture 70(3): 289-302.

16. Lopez-Caballero ME, Perez-Mateos M, Montero P, Borderias AJ (2000) Oyster preservation by high-pressure treatment. J Food Prot 63: 196201.

17. Cadun A, Cakli S, Kisla D (2005) A study of marination of deepwater pink shrimp (Parapenaeus longirostris, Lucas, 1846) and its shelf life. Food Chemistry 90(1-2): 53-59.

18. Pirazzoli P, Ambroggi F, Invertie I, Castelverti F (1986) Study on the possibility of industrial utilization of freshwater Catfish (Ictalurus mlasr). II. Stability during refrigerated and frozen storage. Industerial Conserve 61: 29.

19. Hultin HO (1985) Characteristics of muscle tissue. In: Fennema OR (Eds.), Food Chemistry (2nd Edn). Marcel Dekker, New York.

20. Woyewoda AD, Shaw SJ, Ke PJ, Burns BG (1986) Recommended Laboratory Methods for Assessment of Fish Quality Canadian Technical Report of Fisheries and Aquatic Sciences No. 1448, Fisheries and Oceans, Nova Scotia.

21. Pearson D (1991) The chemical Analysis of Food. In: Churchill, London, Pp. 374-410.
22. Fred J. Baur, Luther G. Ensminger (1997) Association of Official Analytical Chemists (AOAC). Journal of the American Oil Chemists' Society 54(4): 171-172.

23. El-Akeel ATM (1998). Chemical, Microbiological and Sensory Evaluation of Hot Smoked Catfish. Faculty of Agriculture, Cairo University.

24. Goulas AE, Kontominas MG (2005) Effect of salting and smoking method on the keeping quality of chub Mackerel (Scomber japonicus): biochemical and sensory attributes. Food Chemistry 93(3): 511-520.

25. Goktepe I, Moody MW (1998) Effect of modified atmosphere packaging on the quality of smoked catfish. Journal of Muscle Foods 9(4): 375389.

26. Chomnawang C, Nantachai K, Yongsawatdigul J, Thawornchinsombut S, Tungkawachara S (2007) Chemical and biochemical changes of hybrid Catfish fillet stored at $4^{\circ} \mathrm{C}$ and its gel properties. Food Chemistry 103 : 420-427.

27. Abo-Zied KSS (1995) Chemical and histological studies on Carp fish preserved at low temperature. Thesis, Faculty of Agriculture, Cairo University, Egypt.

28. Dokuzlu C (1997) The effect of acid-salt ratio used in the production of Marinated Anchovy to the microbiologic, organoleptic quality and determination of shelf-life of the product. J Pendik Vet Microbial 28: 81-90.

29. Vareltzis K, Koufidis D, Gavriilidou E, Papavergou E, Vasiliadou S (1997) Effectiveness of a natural Rosemary (Rosmarinus officinalis) extract on the stability of filleted and minced fish during frozen storage. European Food Research and Technology 205(2): 93-96.

30. Suvanich V, Marshall DL, Jahncke ML (2002) Microbiological and color quality changes of channel Catfish framemince during chilled and frozen storage. Journal of Food Science 65(1): 151-154.

31. Kose S, Boran M, Boran GK (2006) Storage properties of refrigerated whiting mince after mincing by three different methods. Food chemistry 99(1): 129-135.

32. Ozyurt G, Polat A, Tokur B (2007) Chemical and sensory changes in frozen $\left(-18^{\circ} \mathrm{C}\right)$ wild Sea bass (Dicentrarchus labrax) captured at different fishing seasons. International Journal of Food Science \& Technology 42(7): 887-893.

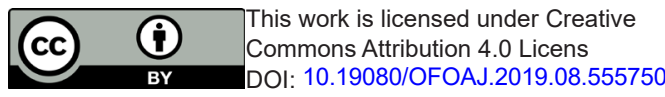

\begin{tabular}{l} 
Your next submission with Juniper Publishers \\
will reach you the below assets \\
- Quality Editorial service \\
- Swift Peer Review \\
- Reprints availability \\
- E-prints Service \\
- Manuscript Podcast for convenient understanding \\
- Global attainment for your research \\
- Manuscript accessibility in different formats \\
( Pdf, E-pub, Full Text, Audio) \\
- Unceasing customer service \\
Track the below URL for one-step submission \\
https://juniperpublishers.com/online-submission.php \\
\hline
\end{tabular}

